\title{
The Development of Educative Game "Word Find" for Instructional Media Based on Android at Elementary School
}

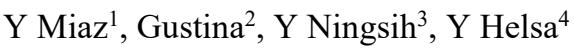 \\ ${ }^{1}$ Universitas Negeri Padang, Jl. Prof Dr. Hamka Air Tawar, Padang, Indonesia ${ }^{1,2,3,4}$ \\ \{gustina625@gmail.com\}
}

\begin{abstract}
The background of the research was the use of educative game which used as instructional media based on android was rarely use even though 21 st century instructional, instructional model and instructional media did not have limitation and done by helping of technology information and communication. This research aims to produce educative game "Word Find" for instructional media based on android which is valid, practical, effective, interesting and fun on social science course. This kind of research was research and development (R\&D). 4-D model was used as development model. The research did in SDN 54 Payakumbuh. The subject of research was grade six students. Validity test data was gotten through media validation sheets by media, material and language expert. Practicality data was gotten through assessment sheet; teacher, students and the parents respond questionnaire. The effectiveness was seen from students learning result. The data was analyzed based on research result. the results of this study are produced educational games that are valid, practical and effective. The results of this study are produced educative games that are valid, practical and effective.
\end{abstract}

Keywords: Educative Game, Word Find, Ndroid, Elementary School

\section{Introduction}

Discovered in the last 20 years, the shifting to development of education to ICT as the one of $21^{\text {st }}$ education management strategy which is consisted to institutional governance and human resources [1]. In this century, the change in all of aspects of education is necessary in order to create the teacher who promote the students knowledge and require the students who have the skill and skill in media technology and information field and the renewable innovation. In 21 st century, there is no limitation on instructional model and done by the helping of technology information and communication. Indonesia education and instruction showed the significant development especially with the development of technology information system (TI). In this time, the education moves dynamic. In fact, the development of technology does not suitable with the application in education field especially in socialscience course in elementary school. The using of instructional media based on educative game in social science instruction is rarely use in Elementary school. based on observation and interview did in SDN 54 Payakumbuh, Payakumbuh Barat Sub-district, 
Payakumbuh. Researcher found some problems in social science course related to instructional media which use in Indonesia natural phenomena and neighbor country material; (1) teacher used inappropriate instructional media like cardboard with natural phenomena pictures which used to help students to understand the Indonesia and neighbor country natural phenomena material, (2) teacher did not follow the development of IPTEK in developing the instructional media, (3) teacher was not able to develop IT bases instructional media, (4) the incomplete of interactive multimedia instruction medium in the form of game which made the students fun and pay attention to learning material, (5) the students were less active during instruction (6) the students were not able to express their own idea and concept and unite the ideas during learning activity.

The above problems effected on the low of students pre- test result and it did not achieve the criteria of the minimal score. The one of innovation which can help to overcome the above problem is the developing of educative game "Word Find" for instructional media based on android used AppsGeyser application. The reason of using AppsGeyser in making educative game because AppsGeyser have advantages which can use to join pictures and other features as a result the games is interesting. In addition, the AppsGeyser can use by anybody, anywhere, anytime with one condition, connected to internet and this application do not need certain computer specification. It is different with the computer application which needs certain specification. AppsGeyser based on web is more simple to use

Android is made to facilitate the communication, but the available of android features can use as instruction media. In elementary school, the using of android to school is taboo but under guidance of teacher, using can be positive if android used to achieve the instructional goals. In 21 st century teacher is not allowed to close their mind toward the development of information. With using android as instructional media, fun learning environment, communicative and interesting learning will be created. The term of "Word Find" derive from the translate of Indonesia words "cari kata" which means the students search for suitable words suitable with learning material.

In the previous research, educative game based on android was tested and used in creating the instructional media based on interactive multimedia. The research,explains that, "the development of educative game "Si Galang" based on android on social science course on traditional costume material for elementary students grade four" was proper to use as alternative instructional media and able to achieve learning result more than minimum score [2]. The research explained that "education game application based on android to promote Indonesia traditional cloths" can help the government to preserve the national culture especially for children [3].

\section{Method}

The design of research is research and development. This kind of study is consisted from systematic planning, developing and evaluation. The research used 4D model consisted from, "define, design, development, and disseminate [4]. The research did at SDN 54 Payakumbuh, West Sumatera, on grade six. The subject of the research were 3 person as validator; one lecturer as media experts, one material expert and one language expert then, the suggestion of from validator used to revise and evaluate of the product. Second, the trial of the product did to teacher and grade six students of SDN 54 Payakumbuh. In the test of educative game media "word find" based on android at social science course was the effectiveness and practicality test. 
The kind of data was qualitative and quantitative data; validity, practicality and effectiveness test. The first instructional media validation data was given by media, material and language expert. The second data was gotten from experiment process. In this step, the data about practicality test (teacher and students respond) and effectiveness test (learning result) was taken. Research and collections of the data was the beginning process of the research, observation in order to measure or did the need analysis to know the problems during instructions [5].

The technique collection of data is using learning evaluation test and observation sheet (effectiveness), questionnaire (validity, practicality) and documentation. Questionnaire was consisted of questionnaire for media expert, material expert, language expert, teacher and students. The type of questionnaire is closed-questionnaire, which means the respondents should choose one options from the available options, the scale was likert scale (5 scales measurement) and guttman scales (yes/no). Data collection process must be accountable for its objectivity, reliability and validity [6]. Data collection instrument is important because evaluation based on the assessment [7]. There were instruments on assessment to collect the data. In this research, questionnaire, test and documentation was used as instrument to collect the data. The data analysis technique was descriptive quantitative which beging with giving score, determine the score with sum up the respondents score, count each of sub variable percentage, determine the validity criteria and instructional media practicality based on percentage value and effectiveness test.

\section{Result and Discussion}

\subsection{Finding}

The research was conducted in SD Negeri 54 Payakumbuh for 3 month, February till april. The research focused on educative game "word find" for instructional media in social science course in elementary school.

\subsubsection{Define Phase}

The result of instructional media need analysis is (1) the incompatibility of instruction media in social science course at grade six on Indonesia and neighbor natural phenomena (2) the instructional media did not displayed the Indonesia and neighbor natural phenomena (3) unavailability of interactive multimedia on social science course at elementary school (4) instructional media based on interactive multimedia can help to increase the learning result and stimulate the students motivation to learn.

The result of curriculum analysis on social course at grade six in elementary school are (1) standard competence; 2. Understand the Indonesia natural phenomena (2) basic competence, 2.1describe Indonesia and neighbor country natural phenomena (3) the objective of instruction: (a) with using educative game "word find", students are expected to be able to identify the name of Indonesia and neighbor natural disaster (b) with using educative game "word find", the students are able to use game in android which useful for instruction and education.

The result of material analysis in instruction media is developed based on syllabus and KTSP instruction material characteristic. Instruction media contains material about the names of natural disaster which happen in Indonesia and neighbor country. The result of media 
analysis, did through school observation, found that educative game for instruction based on android in social science is the new things which developed in elementary school considering the used of android in 21 st century is popular for elementary school students. the result of students analysis are (1) educative game for instructional media based on android was able to increase student learning result on social science subject because teacher did not use it yet, (2) the students were interest to learning and fun to learn by using electronic media such as android, (3) six grade students was able to use android positively.

\subsubsection{Design Phase}

The Design of educative game "word find" for instruction media based on android which developed on grade six at SDN 54 Payakumbuh, West Payakumbuh Sub-district, Payakumbuh, are: (a) instruction material arrangement and lesson plan suitable with material, (b) send letter to the students parent in order to permit the students to bring android to school, (c) composing the evaluations test and key answer (d) selecting of media, educative game "word find" based on android, (e) selecting of format with making design along with instruction media component will make with IT expert, (f) making media design with IT expert.

\subsubsection{Development Phase}

\section{a) Validity Test}

1. Media expert lecturer, The variable which assessed on instruction media validity test is display, readiness, the easiness to use and test. The final assessment toward media are score 4 (A) score 3 (SD). Score 4 was given to 11 indicator (no. 2, 3, 5, 7, 8, 9, 10, 11, 12, 14, and 15) meanwhile score 3 (SD) for 3 indicators (no. 4, 6 dan 13).

2. Material expert lecturer, The variable which assessed on instruction media validity test is content and learning objectives, the material, instructional and test. In general, the final assessment toward material aspect is score 3 (A) and 4 (SA). Indicator with score 3 (no 3,8 and 13) meanwhile the indicator with score 4 (SA) are (no 1, 2, 4, 5, 6, 7, 9, 10, 11, 12, 14, 15 dan 16).

3. Language expert lecturer, The variable which assessed on the aspect of language is grammar, communicative, the media suitability with the development of students and the suitability of social science learning steps. 5n general the final assessment toward language aspect on instructional media got score 4 (SA) and 3 (A). Indicator with score 4 (SA) is number $(1,4,5,7,8$, and 11) and score 3 for number $(2,3,6,9$, and 10).

\section{b) Practicality Test}

Practicality test data based on multimedia is primer data, data which gotten from teacher and students. Questionnaire is used to collect the practicality test data. The experiment subject were teacher and 25 students from grade six SDN 54 Payakumbuh, Payakumbuh Sub-District, Payukumbuh.

\section{c) Effectiveness Test}


The result effectiveness test of educative game "word find" for instructional media based on android was gotten students learning result. The learning result was evaluated from the 3 domain, affective, cognitive and psychomotor.

1. Cognitive domain, The learning result on cognitive domain with using educative game "word find" for instructional media based on android is categorized into very good (VG). The students' total score is 2080 with average 83.20 (VG). The percentage of completeness, 25 students, is $84 \%(\mathrm{G}) .21$ students passed the standard score meanwhile $16 \%$ students or 4 students cannot pass the standard score

2. Affective domain, Recapitulation of students affective score SDN 54 when using educative game can be seen in the following figure

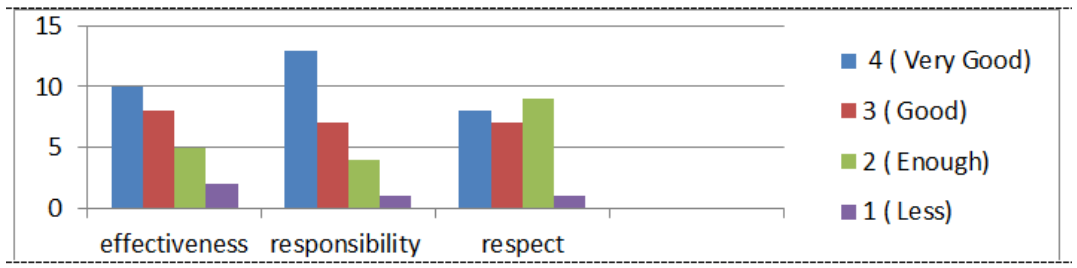

Fig. 1. Recapitulation of affective score

3. Psychomotor domain, Recapitulation of students affective score SDN 54 when using educative game can be seen in the following figure

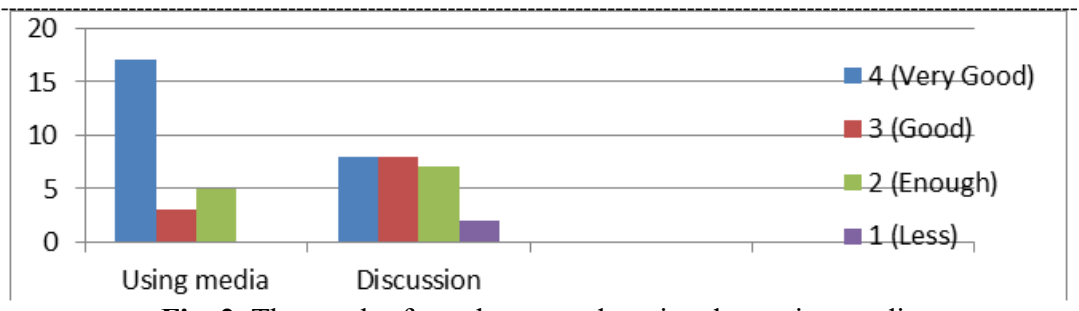

Fig. 2. The result of psychomotor domain when using media

\subsubsection{Development Phase}

Disseminate phase did on Saturday, April 27th 2019 on grade six SDN 28 Payakumbuh, West Payakumbuh sub-district. In this stap, effectiveness test and learning result data was gotten.

\subsection{Discussion}

The result of product assessment toward educative game "word find" for instructional media based on android using AppsGeyser application on social science course at grade six was categorized into very good. It was seen from validity test result which consisted from validity test toward media material and language. The score of validity test in the aspect of media is $93 \%$ which categorized into very good (VG), the score of validity test toward material is $95 \%(\mathrm{VG})$ and the language validity test is $89 \%(\mathrm{VG})$ The result of media practicality test is teacher, students and parents ware good and very good. The assessment of practicality test media by teacher was $82,69 \%$ (VG). The 25 students' assessment is $92,83 \%$ 
(VG), the assessment by parents was $71,21 \%(\mathrm{G})$. in addition, the clear explanation is available on appendices 15,16,and 17 page 201-204 The media effectiveness test can be seen from students learning result; cognitive, affective and psychomotor. In general, the experiment of the product is categorized into good and very good. The average of cognitive aspect is 83.20 (VG) with completeness percentage $84 \%$ from 25 students. The score of affective score is $3.06(\mathrm{G})$ and the average of psychomotor aspect is $3.22(\mathrm{G})$

The result of the research denotes the using of educative game "word find" based android gave positive effect toward social science course in elementary school. In learning and teaching process which using instructional application based on android had several advantages; efficiency on delivering material and increasing student learning interest toward Indonesia and neighbor natural phenomena material.

\section{Conclusion}

Firstly, developing educative game "word find" for instructional media based on android started from need analysis, curriculum analysis, material analysis, media analysis and students' analysis. Afterward, the arranging of material, evaluation test, media selecting, format selecting and initial design. Secondly, validity test result toward instructional media by media expert lecturer is categorized into very good. The first validity by material expert is 3,06 with percentage $77 \%$ is categorized into good. Meanwhile, material expert validity is categorized into good. The last validity by language expert is categorized into very good. Then, in general the result of media practicality test; teacher, students and parents assessment is categorized into good and very good. Fourthly, instructional media effectiveness test showed students in SDN 54 Payakumbuh is increasing compared with students learning result before using educative game "word find" based on android.

\section{Acknowledgments}

Thank you to Universitas Negeri Padang for permitting the research.

\section{References}

[1] Dewi F 2016 Metodik Didaktik: Jurnal Pendidikan Ke-SD-an 92

[2] Hikmah Asril D A R U L and Yermiandhoko Y 2018 Jurnal Penelitian Pendidikan Guru Sekolah Dasar 6419

[3] Candra A T W 2015 Indonesian Journal on Software Engineering 11

[4] Mulyadi. 2017 Kiat Sukses meraih Hibah Penelitian Pengembangan (Yogyakarta: Deepublish)

[5] Titis Prilanto 2015 Pengembangan Alat Permainan Edukatif Kokotar untuk Pembelajaran Tematik Integratif Kelas IV Di SDN Catur Tunggal 3 Sleman Yogyakarta (Yogyakarta:Universitas Negeri Yogyakarta)

[6] M Asrori 2016 Penelitian Tindakan Kelas (Bandung: CV Wacana Prima)

[7] Arifin Z 2012 Evaluasi Pembelajaran (Bandung: PT Remaja Rosdakarya) 